\title{
Conservation Status and Stand Structure of Daterium Woodland in Pandam Wildlife Park, Plateau State, Nigeria
}

\author{
Unanaonwi Okpo Esio* and Ihinmjkaiye Samuel
}

Department of Biology, Federal University, Otuoke, Bayelsa State, Nigeria

*Corresponding author

\begin{tabular}{|l|}
\hline Ke y w o r d s \\
Species dominance, \\
Local communities, \\
Cutting pressure, \\
Declining population, \\
Conservation
\end{tabular}

\section{A B S T R A C T}

Efforts towards species conservation are focused on declining populations with less emphasis on dominant species. This has resulted to a once dominant species in forest ecosystem becoming endangered or at the verge of extinction. The study examined woody plants composition and stand structure of Detarium woodland to ascertain the conservation need of the species and other woody plants in Pandam wildlife Park, Plateau State, Nigeria. Four sample plots $(250 \times 10 \mathrm{~m}$ each) were randomly established across the Daterium woodland. Total enumeration of woody plants of $\mathrm{dbh} 10 \mathrm{~cm}$ and above at breast height (dbh $1.4 \mathrm{~m}$ ) and height of trees were measured. Girth at breast height was measured using a meter tape. Tree height was measured by angular pace method. Descriptive statistics and Simpson Index of Diversity was used in analyzing the data. Results show that the woodland composed of 11 species belonging to six botanical families. The studied samples contained 173 individuals which is 245 trees/ha with Detarium microcapium having $56.65 \%$ total species percentage. The most diverse plant families were Leguminosea (3 species) and Combretaceae (3 species). Vitellaria paradoxa has the largest mean girth $(76.6 \mathrm{~cm})$ and also recorded the tallest with mean height of $23.1 \mathrm{~m}$. Detarium microcapium and Vitellaria paradoxa are currently undergoing cutting pressure in the woodland due to their use values by the communities. Conservation strategies should be vigorously pursued by the Park management to protect these species.

\section{Introduction}

Tropical forests and woodland destruction has recently aroused considerable international concern and has become the focus of several major international conservation programmes. One of the reasons for this growing concern over the future of the worlds' tropical forest lies in their value as home to the greatest wealth of life- forms to be found anywhere on earth (Usher, 1991). It is estimated that between 2 and 4 million of the earth's 5-10 million species live in the tropical forests and woodlands. The destruction of tropical forests and woodlands through industrial and agricultural expansion, including the proliferation of dams, over-gazing of forest vegetation, indiscriminate hunting of wild animals, and the use of poisonous chemical for fishing, have set in motion, changes which make it extremely difficult to protect the ecosystem. This situation informed the emphasis on in-situ conservation programmes such as forest reserves, wildlife parks and 
nature reserves as the most practical way of conserving what is left of our renewable natural resources (FDF, 1995).

At current pace, the human expansion is forcing species to go extinct about 1000 times faster compared to natural process of selection (Stephenson, 1999). The removal of forest cover during logging has in some cases, resulted in the scarcity or extinction of important plant and animal species (Fuwape, 2003). Hamilton and Pearse (1985) stated that the adverse effects of the destruction of forest cover during tree harvesting, resulting in loss of protection which the plant gives to the soil is an indirect loss to microbial populations which keep the ecosystem in a functional state. Uncontrolled timber harvesting interrupts the normal nutrient cycle of the forest, promotes nitrification and increases nutrient leaching, thereby leaving the topsoil impoverished and susceptible to erosion. Meyers (1988) reported that soil under primary forest erodes at an average rate of 12 tons per hectare, while open vegetation in deforested areas of upland topography erodes at the rate of about 84 tons per hectare per year. Accelerated erosion has resulted in gullies in various deforested parts of Nigeria (NEST 1990). Eroded soil are often deposited in rivers and fish ponds thereby causing sulfation and contamination of such water bodies (Fuwape, 2003). Tropical forest and woodland destruction has aroused considerable international concern and has become the focus of several major International Conservation Programmes (Usher, 1991; FDF, 1995; Suzuki, 2013).

The origins of conservation were rooted in a general concern to protect nature because of its intrinsic and aesthetic values. This is important as it became apparent that we should conserve the natural world. It was estimated that the benefits of conserving nature outweighs the cost by $100 \%$. It is easy to understand that plant diversity provides us with all the types of goods that we can use and sell, from clothing to materials and shelter. For example, a few years ago a study in the US stated that it has been estimated that the market for natural products was worth 87 billion US dollar per year. There are several categories of direct use values, which include food, timber, paper, cosmetics and personal care products, biotechnology and traditional medicine, genetics (e.g. for crop breeding), pest control, and recreation (for example, the mired bug, Cyrhorhinus mundulus saved Hawaiinian sugar cane from leaf hoppers). Natural resources can also have specific cultural value (2004).

Whitemore (1997) reported that natural resources provide services that our well-being depends on. For example, one study estimated that the ability of tropical rainforest to mop up carbon dioxide is worth 46 billion US dollar per year. Other ecosystem services include nutrient cycling, climate and hydrological cycle regulation, pollination and tropic vegetation. It is difficult to put a figure on any one of these services but in 1997 a group of authors writing in nature attempted and came out with a figure of 33 trillion US dollar (twice the global GNP) (Akosim, 2007). Efforts to conserve our forest must therefore become a priority.

Plateau State has two wildlife parks one in Jos and the other in Pandam. The two conservation areas are imageries of themselves as there are no biological resource components. Sustainability of the fauna resources in the park depend on how much of the flora resources that can be conserved. This cannot be achieved except the species list and structure of the plant resources in the park is ascertained. LBRB (1982) classified the park into six vegetation types namely DanielaVitellaria Association, Burkea woodland, Detarium-woodland, Isoberlina woodland, 
Riparian forest and the Grassland floodplain. This study is purposely aimed at providing a list of the woody plants composition and stand structure of the Detarium woodland in the park.

\section{Materials and Methods}

\section{Study area}

Pandam wildlife Park is located in the southern part of Plateau State and lies between Latitudes $8^{0} 35^{1} \mathrm{~N}$ and $8^{0} 55^{1} \mathrm{~N}$ and Longitudes $8^{0} 00^{1} \mathrm{E}$ and $10^{0} 00^{1} \mathrm{E}$. It is bounded on the East by Nemu and Kayarda towns, on the West and North by the Dep River and on the South by Aningo and Pandam towns. The monthly temperature ranges from $25.8^{\circ} \mathrm{C}$ in August to $35.7^{0} \mathrm{C}$ in March. The mean monthly rainfall ranges from $0.00-243.5 \mathrm{~cm}$ (Kreshaw, 1979). The wet season extends from December to March. The park lies within the northern guinea savanna and the vegetation is classified (Akosim 2007) into six vegetation types namely Daniela-Vitellaria Association, Burkea woodland, Detarium-woodland, Isoberlina woodland, Riparian forest and the Grassland floodplain. The Park is made up of three distinct habitats, the natural forest with an area of $244 \mathrm{~km}^{2}$, a riparian forest with an area of $22 \mathrm{~km}^{2}$ and savanna woodland with an area of $42 \mathrm{~km}^{2}$. The Detarium woodland covers an area of $10 \mathrm{~km}^{2}$.

\section{Vegetation sampling and data collection}

Four sample plots $(250 \times 10 \mathrm{~m})$ each were randomly established across the Daterium woodland according to the method of Gysel and Lyon (2004). Total enumeration of woody plants species that were $10 \mathrm{~cm}$ dbh and above, girth, and height from the base were measured. The girth at breast height was measured using a meter tape. Tree height was measured by angular pace method (Gysel and Lyon 2004).

\section{Data analysis}

Descriptive statistics and Simpson Index of Diversity was used in analyzing the data.

\section{Results and Discussion}

Results on figure 1 and Table 1 show that the Detarium woodland is composed of 173 trees of $10 \mathrm{~cm} \mathrm{dbh}$ and above which falls into eleven species. Daterium microcapium has the highest number of trees, followed by Afromasis laxiflora and Terminalia glaucescen which have the same number. The least species in terms of number are Combretum molle; Piliostigma thonningii; Pseudoerdrella kotshi; Combretum glutiosum; Erithropheum suaveolen; and Garderia sokotomiasis. All have five trees each.

The Apocynaceae family where Detarium microcarpium belongs (Fig. 2) has the highest percentage of plant, followed by Combretaceae and Leguminsea families. The family Meliacea recorded the least percentage of plant occurrences in the 1ha sample. Table 2 Show that Viterllaria paradoxa has the highest mean girth and height while Combretum molle has the least mean girth and Afromasis laxiflora has the least mean height.

The woodland is composed of 173 woody plants from $10 \mathrm{~cm}$ dbh drawn from 11 families of which Detarium microcarpium has the highest individuals (98) (Table 1). That is equivalent to 245 trees of a single species/ha. This agrees with Akosim (2007) who earlier described it as Detarium woodland meaning that the species is the dominant. Dominance in woody plants population especially among natural forest stand could be brought about by factors such as competition, branching pattern, growth rate, nutrient requirements, nearneighbour tolerance, mean area per plant (a function of tree diameter), as well as perceived use values by local population. 


\section{Causes of competition in forest ecosystem}

Competition and struggles to have it all is not limited to man only, (although unlike the plants man's quest is usually driven by greed) it is a normal trait observable in all biotic communities. Whether in the plantation or natural forest, trees exhibit competitive characteristics for available sunlight, nutrients and moisture. In a stand of diverse species or individuals, individuals that get much of these supplies will eventually outgrow the other and begin to dominate in height, branches, early maturity and fruition, early seed bearing and seed fall for early natural regeneration (SIP 1998). Such species will eventually take over the stand within time. The branching pattern of species could give advantage for that species to dominate others. Some tree branches at $90^{\circ}$, some at $45^{\circ}$ perpendicular to the stem resulting into large canopy areas which create a ceiling over other species under them.

Plant growth rate varies according to species, from fast to slow and where two plants with different growth rates share the same resource in a stand, the species with fast growth rate will dominate the other in population arising from early maturity and regeneration. Sometimes tree dominance could be as a result of species' nutrient requirement which varies across species (Unanaonwi, 2011). If a particular plant could get its needed nutrients readily from the soil where a particular element is lacking but needed by another plant in that same ecosystem, the earlier will dominate the latter.

Near-neighbour-tolerance of some plants results into species dominance in a population. Bada (1997) observed that Eucalyptus exudes toxic substances around it on plantation soil which inhibits the growth of other plants near it. Tree diameter is a factor that account for the number of tree per hectare when calculating for mean area/plant. Trees with larger diameter will occupy greater area of the forest stand and where such species co-exists in the natural forest, it stands out as the dominant species.

For local populations whose livelihood is $75 \%$ dependent on use of woody plants (Unanaonwi and Amonum, 2013), certain species is seen to be more valuable than others according to local perception. In that situation the more valuable of two species would be put under high harvest pressure (Unanaonwi and Amonum, 2013), which lead to decline in population giving way for the less useful species to become a dominant species. The dominance of Detarium microcarpium in the woodland cannot be attributed to nearneighbour intolerance because the species is not known to exhibits that characteristic. This agrees with McNaughton and Wold (1979) that savanna ecosystem is vegetation dominated by grass species with trees forming a scattered open canopy.

The 11 species recorded in the study belongs to 6 families (Fig. 2) where the family Apocynacea which Detarium belongs has the highest percentage $(56.65 \%)$ of trees/ha. The species has above half of the plant population in the study thereby confirming its dominance status. In terms of species diversity, the most diverse plant families are Leguminosea (3 species) and Combretaceae (3 species). The family Meliaceae has the least species in the woodland contributing to least \% total tree in the woodland aside other factors.

\section{What determine harvest pressure on tree} species?

Harvest pressure on species varies from one species to another depending on use values dictated by the local communities as well as emerging markets demands for such products outside the local communities. 
Table.1 Number of individuals per species present in Daterium woodland, Pandam Wildlife Park

$\underline{\text { Species }}$

Daterium macrocarpum

Viterllaria paradoxa

Crossopteryx ferbrifuga

Philostigma thonnigii

Pseudodrella kotshi

Afromamis laxiflora

Combretum molle

Combretum glutiosum

Erithropleum suaveolen

Garderia sokotomiasis

$\underline{\text { Terminnalia glucescen }}$

Total
Number found/1ha

Diversity Index (D)

98

3.1

7

646.8

8

531.3

5

1487.8

5

1487.8

15

141.6

5

1487.8

5

1487.8

5

1487.8

5

1487.8

15

141.6

Table.2 Means of girth and height of species from $10 \mathrm{~cm}$ above in Detarium woodland

\begin{tabular}{|c|} 
Species \\
\hline Detarium microcapum \\
\hline Combretum molle \\
\hline Viterllaria paradoxa \\
\hline Crossopteryx febrifuga \\
\hline Piliostigma thonningii \\
\hline Pseudoerdrella kotshi \\
\hline Afromasis laxiflora \\
\hline Combretum glutiosum \\
\hline Erithropheum suaveolen \\
\hline Terminalia glaucescen \\
\hline Garderia sokotomiasis \\
\hline
\end{tabular}

Mean Girth(cm)

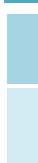

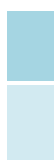

76.6

46.2

50.1

39.8

55.27

48

58

42.7

52
Mean Height (m)

20.69

18.36

23.1

19.0

17.2

18.6

6.66

20.5

21.1

16.8

20.8 
Fig.1 Number of Individuals per species in Detarium Woodland

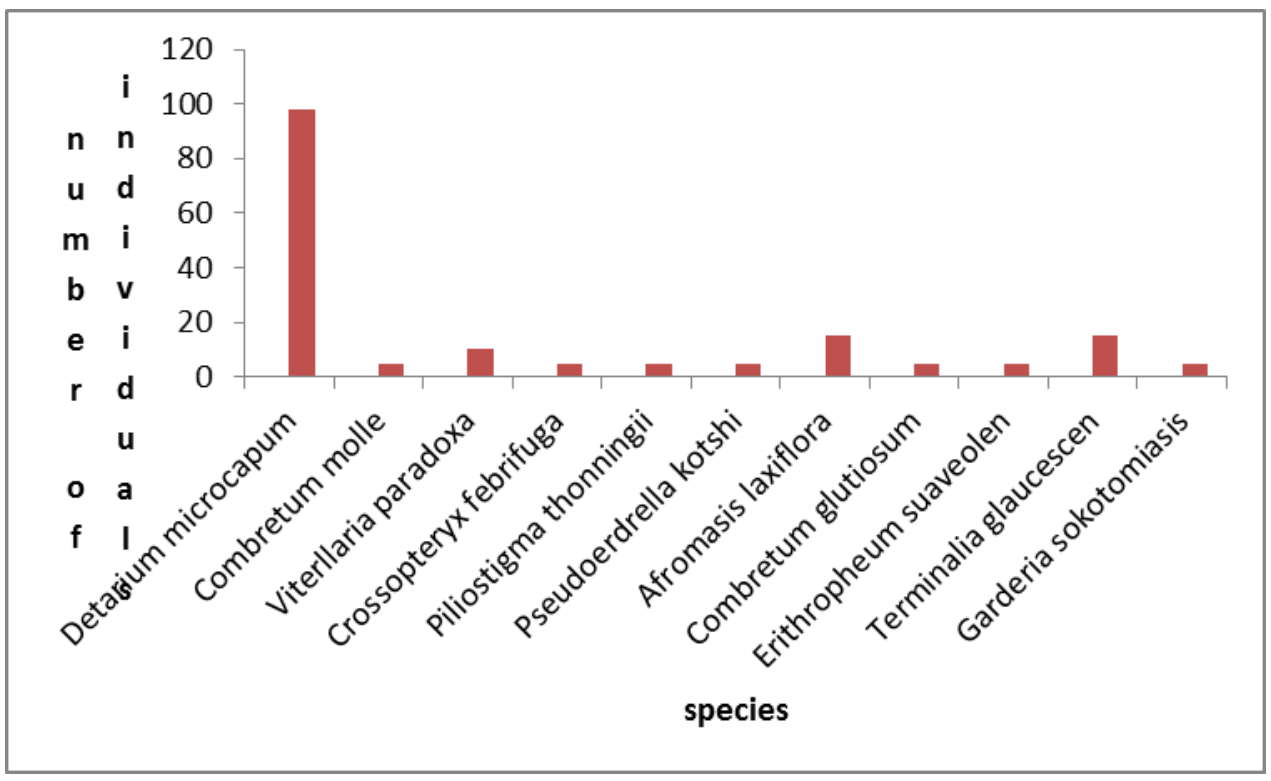

Fig.2 Woody plant species by family (\%/ha) in Daterium woodland

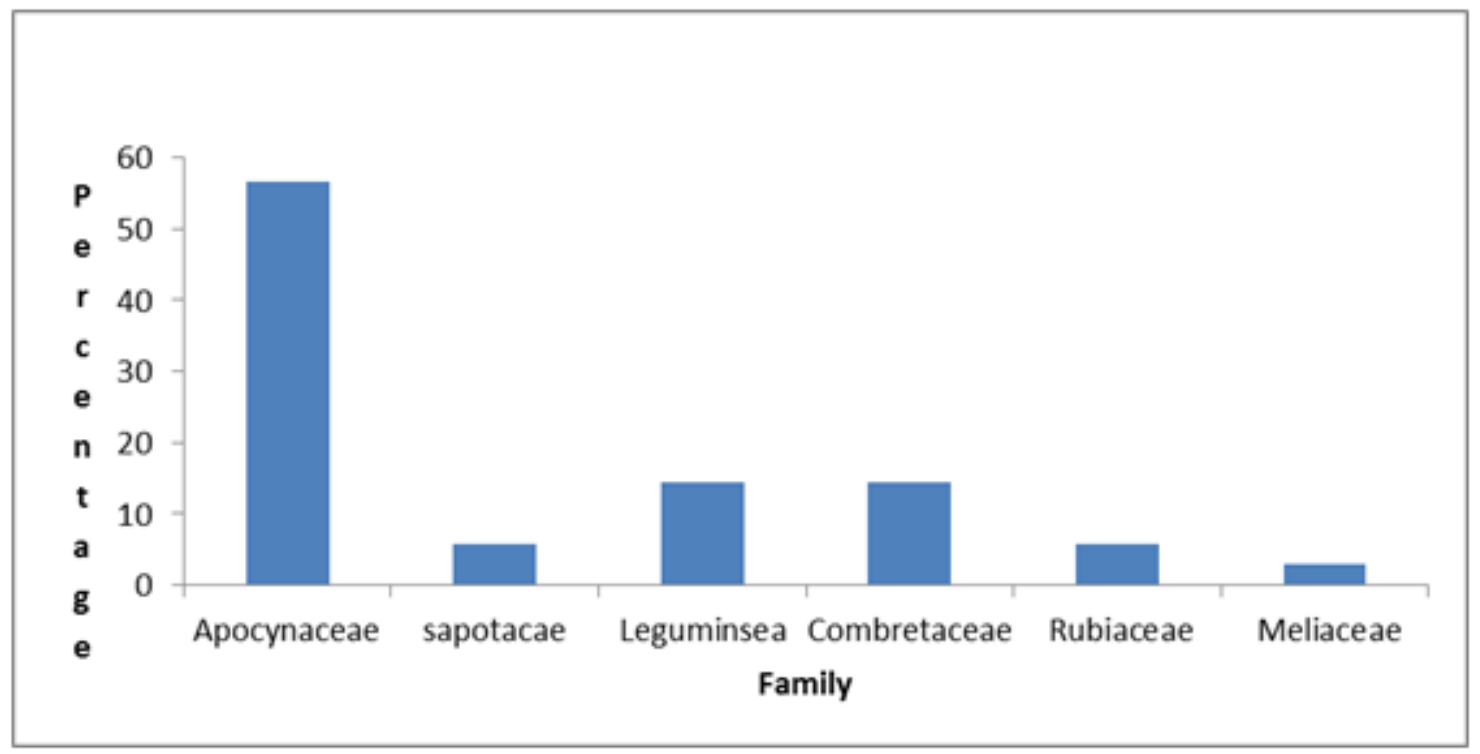

For timber products, emphasis is placed on form, girth and tree height, and woody plants with such characteristics will be under pressure for local use and for market.

Viterllaria paradoxa has the largest mean girth with the tallest mean tree (Table 1). It would be a desirable species for lumber and poles by virtue of height and girth. The longer the bole length, the more the number of sawn logs produced. The larger the log diameter the more the number of sawn products (planks) produced.

Observation revealed that Viterllaria paradoxa in the park generally is under cutting pressure evident by number of stools found here and there in the park. 
Afromasis laxiflora is the shortest species but has a robust mean girth. Though it may not be a good choice for pole, it is suitable for use as sawn wood. Tree height and girth are two main indices in measuring yield of forest trees because the amount of specified sawn-logs and the number of sheets of lumber produced depend on the bole height and the girth of tree. This is reflected on the cutting pressure exerted on species like Viterllaria paradoxa; Garderia sokotomiasis; Afromasis laxiflora ; Detarium microcapum; Combretum molle; Piliostigma thonningii; Crossopteryx febrifuga which possesses mean girths of $45 \mathrm{~cm}$ and above with mean heights of $19 \mathrm{~m}$ and above. Fellers whether legal or illegal will always go for the tallest tree or the largest diameter.

Although Detarium microcapum remained the highest in population in the woodland, yet it undergoes extraction pressure because of its use values in traditional healthcare among the rural communities surrounding the park. The bark is boiled and drank by women who newly put- to- bed for the purpose of tranquilizing pain and constriction of the birth canal, and to trigger milk production. The bark is dried and grinded into powdery form and sold in the market popularly. Viterllaria paradoxa is the most structurally prominent in height and girth among the species investigated. The short height of Afromasis laxiflora among the species is a prominent stand structure.

The study assessed the woody plants composition and stand structure of Detarium woodland in Pandam wildlife Park in Plateau State of Nigeria. The woodland is composed of eleven species belonging to six families. Two species: Viterllaria paradoxa and Detarium microcapium undergoes cutting pressures due to their use values as recognized by the local communities surrounding the park.
The botanical family Leguminosea and Combretaceae were the most diverse species in the woodland, each having three different species. Although Detarium microcapium dominates the woody plant vegetation, the species stands the danger of being replaced by other species with less use values because of the high rate of removal for various uses. There should be a concerted effort towards the conservation of Detarium microcapium and Viterllaria paradoxa by the park management to forestall a likely depletion in the near future.

\section{References}

Akosim, C, Kwanga, BT, Ali, A. and Mamman, GS. 2007. Flora Resources and Structure in Pandam Wildlife Park, Pandam, Plateau State, Nigeria. Agricultural Journal, 2 (6) 740-747.

Bada, SO. 1997. A comparative study of the Growth of Obeche (Triplochyton sclerenxylon $\mathrm{K}$. schum) under plantation and natural forest conditions. M.Phil dissertation. Department of Forest Resources Management University of Ibadan, Nigeria.ix +89 .

Federal Department of Forestry (FDF). 1995. National Conservation Strategy for Nigeria. Rep. Submitted Federal Govt. Nigeria, pp. 1-75.

Fuwape, JA. 2003. The Impacts of Forest Industries and Wood Utilization on the Environment. Paper submitted to the XII World Forestry Congress, Canada. pp. 7.

Grombridge, B. 2000. Ecosystem Biodiversity Microsoft Encarta encyclopedia Premium Suite.

Gysel, WL, and Lyon, JL. 2004. Habitat Analysis and evaluation In Wildlife Management Technique. Wildlife Soc. Inc., pp 305-326.

Hamilto, LS and Pearce, JA. 1985. What are the Soil and Water benefits of Plant 
trees in Developing Country Watershed? In: Proceedings of International Symposium on Sustainable development of Natural Resources, Ohio, USA.

Kershaw, RA. 1979. Quantitative and Dynamic Plant Ecology. ( $2^{\text {nd }}$ edn.). Edward Arnold Ltd. London. Pp 1-308.

LBRB (Lower Benue River Basin). 1982. A feasibility Report on the Irrigation of Dep River Basin. Federal Ministry of Agriculture Handbook. P.2.

McNaughton, JS and Wold, LL. 1979. General Ecology (2 $2^{\text {nd }}$ ed.). Holt Rinehart and Wiston Inc. USA. pp 1702.

Meyers, NA. 1988. Environmental Degradation and some Economic Consequences in the Philippines. Environmental Conservation, 15(3): 205-214.

NEST (Nigerian Environmental Study Team). 1990. A Natural Profile, Nigerian Environmental Studies Action Team, Intec Publishers, Ibadan. pp. 288.

SIP (Smithsonian Institute Press). 1998. Washington D.C. pp 465-478.

Stephen, DS. 1999. The Importance of Conventional Biological diversity to the Liota Maasai of Kenya. In: Posey, D. (ed.). Cultural and Spiritual Values of Biodiversity: United Nations
Environment Program, Nairobi, Kenya, pp. 18.

Suzuki, DE. 2013. Importance of Biodiversity. http//www.davisuzuki.org/ biodiversity/importance. Retrieved $2^{\text {nd }}$ February, 2013.

Unanaonwi, OE and Amonum, JI. 2013. Evaluation of Woody Plants used by Pandam, Namu and Kayarda Communities in Tropical woody Savanna, Nigeria. Agriculture, Forestry and Fish eries. Vol.2, No. 3, 2013, pp. 151-155.

Unanaonwi, OE.2011. Effects of Nitrogen, calcium and cation exchange capacity on gum yield in Acacia senegal under plantation and savanna woodland conditions in northern Guinea savanna, Nigeria. iForest, 4: 190-194.

Usher, MB. 1999. Biodiversity, a Scientific Challenge for Resources Managers. In Proceedings of International Symposium on Biodiversity by ADENA-WWD and Scope. Pp. 33-40.

Whitemore, TC. 1997. Tropical Forest disturbance, disappearance and species loss. In Tropical Forest Remnants edited by W.F. Laurence and K.O. Bierregaard. Chicago University Press. pp. 3-12.

\section{How to cite this article:}

Unanaonwi Okpo Esio and Ihinmjkaiye Samuel. 2018. Conservation Status and Stand Structure of Daterium Woodland in Pandam Wildlife Park, Plateau State, Nigeria. Int.J.Curr.Microbiol.App.Sci. 7(11): 3285-3292. doi: https://doi.org/10.20546/ijcmas.2018.711.379 